Mariola Jaworska

Uniwersytet Warmińsko-Mazurski w Olsztynie mariola.jaworska@uwm.edu.pl

\title{
INDYWIDUALNY STYL UCZENIA SIĘ A PREFEROWANE STRATEGIE - STUDIUM PRZYPADKU UCZNIA DYSLEKTYCZNEGO
}

\author{
Individual learning style and preferred strategies. \\ A case study of a dyslectic student
}

\begin{abstract}
The aim of the article is to indicate the correlations between an individual learning style of a dyslectic child and their preferred strategies. The first part of the article discusses the developmental dyslexia which is considered to be the reflection of individual learning differences. The second part presents the portrait of a dyslectic student with particular emphasis put on their individual learning style and applied strategies. The final part of the text includes an attempt to indicate practical implications in the context of shaping autonomous attitudes of students with developmental dyslexia.
\end{abstract}

Keywords: developmental dyslexia, dyslectic student, individual learning style, learning strategies

Słowa kluczowe: dysleksja rozwojowa, uczeń dyslektyczny, indywidualny styl uczenia się, strategie uczenia się

\section{Uwagi wstępne}

Dysleksja rozwojowa należy do specyficznych trudności w uczeniu się i obejmuje: trudności występujące w uczeniu się czytania (dysleksja), skojarzone z nimi lub występujące samodzielnie trudności w opanowaniu poprawnej pisowni (dysortografia), trudności w budowaniu zdań, tworzeniu tekstu, wypowiadaniu się na 
piśmie (trudności w komunikacji pisemnej), a także trudności w opanowaniu poziomu graficznego pisma, uwarunkowane obniżonym poziomem sprawności ruchowej oraz zaburzeniami planowania i wykonywania ruchów podczas pisania (dyspraksja, dysgrafia) (Bogdanowicz, 2012: 44).

Ostatnie dwudziestolecie przyniosło duży postęp w rozumieniu tego zjawiska oraz zwiększenie świadomości znaczenia specyficznych trudności dla postępów w nauce szkolnej. Ponieważ występują one - często w nasilony sposób - również podczas nauki języka obcego, stanowią istotny przedmiot rozważań glottodydaktycznych. Analizuje się proces uczenia się języków obcych uczniów dyslektycznych oraz poszukuje sposobów ich wsparcia w edukacji obcojęzycznej. Dość liczne doniesienia naukowe na ten temat dotyczą zazwyczaj młodszych uczących się, znajdujących się na pierwszym i drugim etapie edukacyjnym, niewiele z nich porusza natomiast problemy młodzieży, uczącej się na trzecim i czwartym etapie.

Wydaje się, że dla młodzieży z dysleksją rozwojową niezwykle ważna może być znajomość własnego stylu uczenia się oraz stosowanych strategii. Determinuje bowiem rozwijanie aktywnej i odpowiedzialnej postawy poprzez np. stosowanie celowych, efektywnych strategii uczenia się, opartych na mocnych stronach i preferencjach. Jest też niezbędnym warunkiem przejmowania odpowiedzialności za własny proces uczenia się, także w ramach przygotowania do pracy samodzielnej i kształcenia ustawicznego. Uwzględnianie stylu uczenia się uczniów oraz stosowanych strategii jest również ważnym zadaniem, które stoi przed nauczycielem języka obcego. Za możliwe i skuteczne należy bowiem uznać - szczególnie w przypadku uczniów dyslektycznych na poziomie szkoły ponadgimnazjalnej - wprowadzanie działań stymulujących ich do przejmowania odpowiedzialności za własną naukę i za własny rozwój. Tym bardziej, że uczniowie w wieku 16-19 lat w o wiele większym stopniu niż uczniowie szkół podstawowych i gimnazjów są skłonni do refleksji nad własnym uczeniem się, lepiej potrafią wyznaczać cele nauki i obiektywniej się oceniać. Dlatego wciąż aktualna jest potrzeba prowadzenia badań w tym zakresie.

Celem niniejszego artykułu jest wskazanie na związki pomiędzy indywidualnym stylem uczenia się ucznia szkoły ponadgimnazjalnej ze stwierdzoną dysleksją rozwojową a strategiami stosowanymi przez niego podczas nauki języków obcych. W pierwszej części zostaną zasygnalizowane perspektywy, w których można analizować zagadnienie dysleksji, w drugiej, zasadniczej, będzie zaprezentowane studium przypadku wykorzystujące różne techniki zbierania danych, umożliwiające dotarcie do osobliwości i złożoności badanego obszaru. 
Indywidualny styl uczenia się a preferowane strategie - studium przypadku...

\section{Dysleksja rozwojowa - różne ujęcia problemu}

W dość obszernej literaturze przedmiotu dysleksja rozwojowa jest analizowana zazwyczaj w kategorii deficytu poznawczego, jako zaburzenie, niesprawność, niezdolność. Na takie ujęcie wskazuje też włączenie jej do międzynarodowych klasyfikacji chorób i zaburzeń (DSM-IV, 2000; ICD-10, 2002). Jednak specjaliści zajmujący się tą tematyką podkreślają, że dysleksja nie jest chorobą, a raczej pewną odmiennością w uczeniu się umiejętności czytania, poprawnej pisowni i umiejętności wypowiadania się na piśmie (Bogdanowicz, 1994: 41).

Postrzeganie dysleksji jako inności w budowaniu i posługiwaniu się systemem językowym pozwala na rozpatrywanie tego zagadnienia w kontekście różnic indywidualnych między ludźmi (Bogdanowicz, 2012; Dyrda, 2004). Dotyczą one specyficznych dla danej osoby zachowań psychicznych i poznawczych, wpływających na uczenie się i warunkujących potrzeby, tempo uczenia się i doświadczenia ucznia (Wilczyńska, 1999: 107). Odnoszą się więc do stylu uczenia się.

Zakładając, że styl to „dominujący sposób, a zarazem stosunkowo stały wariant zorganizowania przebiegu określonej czynności poznawczej lub działania" (Nosal, 2000: 470), styl uczenia się języka obcego można zdefiniować jako wielowymiarowy profil preferencji ucznia, reprezentujących i charakteryzujących jego proces uczenia się języka. Profil ten tworzą: podstawowe cechy osobowości, typowe tryby przetwarzania informacji, cechy osobnicze mające wpływ na interakcję jednostki w określonym kontekście społecznym oraz preferencje dotyczące określonych form nauczania (Lesiak-Bielawska, 2007: 31 i n). Szczególne znaczenie dla określenia stylu uczenia się języka obcego uczniów dyslektycznych mają preferencje w zakresie zmysłowego odbioru informacji i narracji, gdyż powodują zróżnicowany odbiór treści przekazywanych przez nauczyciela podczas lekcji wszystkim w taki sam sposób.

Istnieją trzy podstawowe systemy sensoryczne, za pomocą których ludzie odbierają dochodzące do nich bodźce oraz je relacjonują: wzrokowy (wizualny), słuchowy (audytywny) i kinestetyczno-czuciowy. Wzrokowcy uczą się najlepiej, oglądając materiał graficzny i otaczający ich świat lub czytając, słuchowcy - słuchając i rozmawiając, natomiast osoby wykorzystujące trzeci kanał, poruszając dużymi mięśniami ruchowymi, dotykając przedmiotów, przeżywając materiał emocjonalnie. I choć informacje odbierane są zazwyczaj ze świata zewnętrznego w sposób polisensoryczny, jeden ze zmysłów jest podstawowym, odruchowo uaktywnianym zmysłem preferowanym. Są również osoby, które w procesie uczenia się posługują się dwoma lub nawet trzema systemami (Linksman, 2000: 13; Rose i Taraszkiewicz, 2010: 17 i n.).

Różnice w sposobie odbierania informacji wynikają także z preferencji w zakresie dominacji lewej lub prawej półkuli podczas procesu przetwarzania 
i magazynowania danych w mózgu. Osoby z dominującą lewą półkulą preferują analizę, konkretne treści i zadania. Charakteryzuje je myślenie naukowe, podejście intelektualne, bez angażowania emocji. Zatem uczeń z dominacją lewej półkuli mózgu jest zazwyczaj punktualny, dba o szczegóły, bardzo się stara i kontroluje, myśli linearnie, jest nastawiony na wyniki. Ludzie z dominującą prawą półkulą preferują ruch, obrazy, muzykę, zabawę. Cechuje ich duża wyobraźnia i kreatywność, w swoich działaniach kierują się intuicją i emocjami. Uczeń z dominacją prawej półkuli jest więc bardziej nastawiony na to, co dzieje się „tu i teraz”, preferuje działanie, wspólne uczenie się i uczenie się poprzez zabawę (Rose i Taraszkiewicz, 2010: 61 i n.).

Związki pomiędzy indywidualnym stylem uczenia się a dysleksją były analizowane m.in. przez Wszeborowską-Lipińską (1997), która dokonała także obszernego przeglądu literatury na ten temat, zaś badania empiryczne $w$ tym zakresie prowadziła Dyrda (2004; por. Jaworska, 2015). Rozważania te nie dotyczyły jednak nauki języka obcego.

\section{Studium przypadku ucznia dyslektycznego}

\subsection{Organizacja i przebieg badania}

Badanie, którego wyniki zostaną przedstawione w niniejszym artykule, zostało przeprowadzone w maju 2015 roku. Jego celem było znalezienie związków pomiędzy indywidualnym stylem uczenia się ucznia liceum ogólnokształcącego, Jarka (imię zostało zmienione), u którego stwierdzono dysleksję rozwojową, a preferowanymi przez niego strategiami uczenia się w odniesieniu do nauki języków obcych. W celu uzyskania danych zastosowano studium przypadku - metodę szczególnie uzasadnioną w sytuacji analizy wąsko sprofilowanego problemu, badanego w danym kontekście edukacyjnym, umożliwiającą uwzględnienie złożoności pewnego zjawiska (Komorowska, 1989: 18; Bauman, 2001: 279, 337; Wilczyńska i Michońska-Stadnik 2010: 154). Słabe strony tej metody badań, z których trzeba zdawać sobie sprawę, wiążą się z możliwością wybiórczego podejścia badacza do gromadzonego materiału badawczego, pochopnym wyciąganiem wniosków i formułowaniem zbyt daleko idących uogólnień (Bauman, 2001: 299 i n.; Łobocki, 2006: 308).

Pierwszy etap procedury badawczej służył scharakteryzowaniu ucznia i - pomocniczo - określeniu stopnia jego samodzielności. W tej części w pierwszej kolejności dokonano analizy dokumentów: opinii wystawionych przez poradnie psychologiczno-pedagogiczne, zeszytów ucznia, innych wytworów jego pracy. Następnie zastosowano kwestionariusz Delta ${ }^{1}$ służący do pomiaru zmiennej

\footnotetext{
${ }^{1}$ Kwestionariusz Delta bada umiejscowienie poczucia kontroli, czyli przekonanie o posiadaniu wpływu na własne życie lub przekonanie, że zależy ono od zewnętrznych okoliczności.
} 
osobowościowej zwanej poczuciem kontroli, opisanej w teorii społecznego uczenia się Rottera (Drwal, 1979: 69 i n.). Z badań wynika, że istnieje związek pomiędzy umiejscowieniem ośrodka kontroli a osiągnięciami szkolnymi - uczniowie $z$ wewnętrznym poczuciem kontroli osiągają lepsze wyniki w nauce, poświęcają więcej czasu na zadania domowe, są bardziej wytrwali w rozwiązywaniu problemów.

Aby uzupełnić obraz Jarka, podjęto też próbę określenia stopnia jego samodzielności w odniesieniu do nauki języka angielskiego i języka niemieckiego, przy czym ten pierwszy jest jego językiem wiodącym. W tym celu została zastosowana ankieta opisująca zachowania o charakterze autonomicznym, opracowana przez Pawlaka (2008: 142-146) 2. Zadaniem ucznia było określenie w skali od 1 do 5, w jakim stopniu dane stwierdzenie go opisuje, przy czym 1 oznaczało - nie dotyczy, zaś 5 - doskonale opisuje. Jako uzupełnienie tego zadania zastosowano także arkusz zawierający pytania otwarte, dzięki którym było możliwe uzyskanie bardziej szczegółowych informacji na temat stosunku ucznia do nauki języków oraz podejmowanych w tym zakresie działań ${ }^{3}$.

Pierwszym zadaniem drugiego etapu postępowania badawczego było ustalenie indywidualnego stylu uczenia się ucznia. W tym celu zostały zastosowane testy umożliwiające ustalenie preferencji w zakresie stosowanych systemów

Jest przeznaczony przede wszystkim do badania młodzieży szkolnej i studenckiej. Składa się z 24 stwierdzeń, które badany ocenia jako prawdziwe lub fałszywe: 14 z nich należy do skali poczucia kontroli (LOC), określającej umiejscowienie poczucia kontroli, 10 do skali kłamstwa (KŁ), mającej za zadanie ocenę tendencji do przedstawiania się w nadmiernie korzystnym świetle. Za odpowiedź zgodną z kluczem badany otrzymuje 1 punkt. Maksymalny wynik w skali LOC to 14 punktów, a w skali kłamstwa KŁ - 10 punktów. Wysoki wynik w skali poczucia kontroli (LOC) wskazuje na poczucie kontroli zewnętrznej, a wysoki wynik w skali kłamstwa (KL) na tendencję do przedstawiania się w nazbyt korzystnym świetle.

${ }^{2}$ Ankietę opracowano na podstawie zestawień cech i zachowań autonomicznych często cytowanych $w$ literaturze przedmiotu oraz już istniejących narzędzi tego typu. Kwestionariusz składał się z 20 stwierdzeń opisujących zachowania o charakterze autonomicznym. Dotyczyły one m.in. umiejętności oceny własnych postępów, zdolności wyznaczania celów nauki, określania sposobów ich osiągania i dokonywania wyboru materiałów, gotowości do samodzielnego rozwiązywania napotkanych problemów, chęci używania języka poza szkołą, wiary we własne umiejętności.

${ }^{3}$ Uczeń został poproszony o uzasadnienie, dlaczego lubi lub nie lubi uczyć się języków obcych, podanie form pozaszkolnego kontaktu z językami, określenie swoich mocnych i słabych stron oraz określenie celu, jaki chciałby osiągnąć w zakresie uczenia się języków obcych. Jego zadaniem było również wskazanie różnic pomiędzy nauką języków obcych i innych przedmiotów szkolnych oraz scharakteryzowanie samodzielnej nauki w domu (Pawlak, 2008: 143). 
sensorycznych oraz dominującej półkuli mózgowej (Linksman, 2000: 22-35). Ich wyniki mogą dostarczyć istotnych informacji na temat sposobu uczenia się badanego oraz przetwarzania i przechowywania przez niego informacji.

Kolejnym elementem drugiej fazy było zbadanie, jak często uczeń stosuje strategie uczenia się. Ich wykorzystanie określono przy pomocy kwestionariusza zawierającego zestawienie strategii opracowane na podstawie definicji i klasyfikacji strategii uczenia się Oxford $(1990,2002)$. W rozumieniu tej badaczki strategie to określone działania, zachowania, kroki czy też techniki stosowane przez uczniów w celu uzyskania lepszych wyników w uczeniu się. Oxford rozróżnia dwie grupy strategii mających bezpośredni lub pośredni wpływ na uczenie się języka. Wśród strategii bezpośrednich, rozumianych jako „narzędzia intelektualne” do konkretnej pracy nad językiem, wyróżnia strategie pamięciowe, kognitywne oraz kompensacyjne. Strategie pośrednie wspierające proces uczenia się obejmują strategie metakognitywne, afektywne oraz społeczne (Oxford, 1990: 1, 2002: 124). Pomocniczo w tworzeniu kwestionariusza wykorzystano także propozycję Nyckowskiej (2006: 370-373) ${ }^{4}$.

Kwestionariusz został podzielony na 17 zestawów sformułowań w obrębie dwóch głównych grup strategii (łącznie 55 sformułowań). Strategii bezpośrednich dotyczyły zestawy sformułowań: A - strategie pamięciowe (1-4), B strategie kognitywne (5-8), C - strategie kompensacyjne (9-10), natomiast strategii pośrednich: D - strategie metakognitywne (11-13), E- strategie afektywne (14-15), F - strategie społeczne (16-17). Badany miał ustosunkować się do stwierdzeń, stosując skalę od 1 do 5, przy czym 1 oznaczało, że danej strategii nie stosuje nigdy lub prawie nigdy, a 5, że wykorzystuje zawsze lub prawie zawsze. Wymogi formalne związane z objętością artykułu uniemożliwiają załączenie kwestionariusza.

W ostatniej fazie badania, obejmującej analizę zebranych materiałów, zastosowano także technikę wywiadu, przy czym był on wywiadem nieskategoryzowanym, określanym także jako otwarty wywiad pogłębiony lub wywiad jakościowy (Bauman, 2001: 327). Indywidualne, rejestrowane rozmowy pozwoliły na pogłębienie tematu, poproszenie o argumentację niektórych stwierdzeń zawartych w ankiecie i wyjaśnienie wielu kwestii.

\footnotetext{
${ }^{4}$ Autorka opracowała narzędzia służące samoocenie motywów, strategii, postaw oraz wiedzy i umiejętności w zakresie uczenia się gramatyki języka francuskiego w klasie maturalnej. Jednym z narzędzi był kwestionariusz poświęcony badaniu uczniowskich strategii uczenia się gramatyki języka francuskiego, opracowany na podstawie klasyfikacji strategii uczenia się Oxford, który stał się inspiracją do stworzenia kwestionariusza zastosowanego w badaniu opisywanym w niniejszym artykule.
} 


\subsection{Analiza zebranego materiału}

Jarek jest uczniem drugiej klasy liceum ogólnokształcącego o profilu matematyczno-fizycznym. Opinię poradni psychologiczno-pedagogicznej, w której stwierdzono u niego dysleksję rozwojową, otrzymał, gdy był uczniem drugiej klasy gimnazjum. Była to druga diagnoza, pierwsza została przeprowadzona, gdy był jeszcze w szkole podstawowej.

W wyniku przeprowadzonych w poradni badań u chłopca stwierdzono deficyty rozwojowe w zakresie koordynacji i organizacji wzrokowo-ruchowej w obrębie funkcji analizatora wzrokowego, co objawia się także obniżoną sprawnością manualną. Do jego głównych problemów należy niski poziom organizacji percepcji wzrokowej oraz słaba koordynacja wzrokowo-ruchowa. Uczeń ma trudności z ujmowaniem relacji części do całości i wyróżnianiem głównych części złożonych figur. Nieprawidłowe łączenia liter, złe proporcje liter w wyrazie, ich nierównomierne i niejednolite położenie powodują, że pismo jest mało czytelne lub nieczytelne. Utrudnia to odczytywanie zapisanych przez chłopca treści i świadczy o zaburzonym funkcjonowaniu kinestetyczno-ruchowym.

W wyniku badań psychologicznych stwierdzono, że możliwości intelektualne chłopca kształtują się w górnej granicy przeciętnych wymagań dla wieku. Jego mocną stroną jest wysoka sprawność rozumowania logicznego, ujmowania istotnych cech pojęć, uogólniania, rozumowania przez analogię. Umożliwia mu to logiczne przyswajanie nowych treści i samodzielne rozwiązywanie problemów. Ponadto uczeń prezentuje odpowiednią motywację do nauki i zależy mu na osiąganiu dobrych wyników.

Wysoka motywacja i duże zaangażowanie nie znajdują odzwierciedlenia w osiągnięciach szkolnych Jarka. Na podstawie analizy dokumentów szkolnych, uzupełnionej rozmowami z nauczycielami, można stwierdzić, że ma przeciętne wyniki w nauce języków obcych - każdy semestr kończy z oceną dostateczną. Także większość ocen cząstkowych to oceny dopuszczające oraz dostateczne (podobnie wygląda sytuacja w zakresie języka polskiego). Analiza zeszytów i innych wytworów jego pracy, np. wypracowań, pozwala stwierdzić, że prace pisemne są właściwie nieczytelne. Dużo lepsze oceny uzyskuje z przedmiotów matematyczno-przyrodniczych, przy czym średnia jego ocen wynosi 3,8. Uczeń ma osiągnięcia sportowe, głównie w zakresie trenowanych dyscyplin (pływanie i strzelanie). Przez nauczycieli postrzegany jest jako bardzo zmotywowany, pilny i zdyscyplinowany.

Jarka charakteryzuje wewnętrzne umiejscowienie poczucia kontroli, o czym świadczy bardzo niski wynik w skali LOC (1). Oznacza to, że nie przypisuje przysłowiowemu szczęściu czy okolicznościom wiele znaczenia i uważa, że największy wpływ na efekty swych działań ma on sam. Przeciętny wynik w skali kłamstwa wskazuje na brak tendencji do przedstawiania siebie w nazbyt korzystnym świetle. 
Wyniki analizy kwestionariusza zawierającego zestawienie cech i zachowań autonomicznych w odniesieniu do nauki języka angielskiego i niemieckiego bardzo się różnią (zauważalna jest niska motywacja do nauki języka niemieckiego). Średnia 4,25 w przypadku angielskiego wskazuje na wysoką zdolność do podejmowania samodzielnych działań w nauce tego języka, a co za tym idzie wysoki poziom autonomii. Jeśli chodzi o język niemiecki, średnia wynosi 2,95, co również wskazuje na jej dość wysoki stopień. Warto odnotować, że $w$ ankiecie dotyczącej nauki języka angielskiego jedyne stwierdzenie, które uzyskało najniższy wynik, 3 punkty, dotyczyło sposobów uczenia się: „Wiem, jakich używać technik i strategii, aby lepiej uczyć się i używać języka angielskiego". Pozostałe stwierdzenia kwestionariusza uczeń uznał za opisujące go dobrze (4 punkty) i doskonale (5 punktów).

Wypowiedzi ucznia w dodatkowym arkuszu zadań są dość lakoniczne. Stwierdza w nich, że lubi się uczyć języków obcych, gdyż dają możliwość porozumiewania się z osobami mówiącymi w innych językach. Pozaszkolne formy nauki języka obejmują w jego przypadku oglądanie zagranicznych filmów i czytanie zagranicznej prasy. Różnica pomiędzy nauką języków obcych a innych przedmiotów szkolnych polega zaś na tym, że „Aby nauczyć się języka, trzeba się nim w miarę często posługiwać”. Uczeń ma problem z podaniem mocnych i słabych stron - jego odpowiedzi w tym zakresie są krótkie i dość powierzchowne. Jako swoje mocne strony Jarek podaje naukę słówek, w części dotyczącej słabych - gramatykę (nie wymienia pisania). Cel, jaki chciałby osiągnąć w zakresie nauki języków obcych do końca roku szkolnego, to: „Poprawa wypowiedzi". Trudno te stwierdzenia uznać za przejaw większej świadomości w odniesieniu do tego, nad czym powinien pracować.

Wyniki analizy testu pozwalającego ustalić preferencje sensoryczne oraz dominującą półkulę mózgową wskazują na to, że uczeń prezentuje styl kinestetyczno-czuciowy (z bardzo dużym wskazaniem na obszar związany z ruchem), na drugim miejscu znajduje się system słuchowy, a na trzecim - wzrokowy. Charakteryzuje go tendencja do posługiwania się lewą półkulą mózgową. W świetle badań psychologicznych oznacza to, że jego proces uczenia się stanie się bardziej efektywny, jeśli będzie pracować w sposób zorganizowany i systematyczny, angażując ruchowo swoje ciało i mięśnie. Najwłaściwszymi formami pracy wydają się gry edukacyjne, które mają określone reguły i wykonywane są krok po kroku, symulacje, odgrywanie ról, ćwiczenia z wykorzystaniem materiałów, których można dotykać i którymi można manipulować. Samo słuchanie wykładów i werbalnych instrukcji nie będzie wystarczające, gdyż uczenie się jest dla kinestetyków czynnością dynamiczną, opartą na ruchu i słowie (Linksman, 2000: 123-130). 
W ankiecie dotyczącej stosowania strategii badany uzyskał łącznie 199 punktów na 275 możliwych, przy czym najczęściej używa strategii społecznych (średni wynik: 4,6). Oznacza to, że zazwyczaj zwraca się z prośbą o wyjaśnienia, gdy czegoś nie rozumie, upewnia się, czy wypowiedź jest poprawna i prosi o poprawę ewentualnych błędów. Chętnie współpracuje z koleżankami i kolegami oraz zaawansowanymi użytkownikami języka, stara się poznawać kulturę kraju języka docelowego i zrozumieć różnice kulturowe.

Na drugim miejscu pod względem częstotliwości stosowania znajdują się strategie kognitywne (średni wynik: 4,07), przy czym odpowiedź „zawsze lub prawie zawsze" pojawiła się przy wszystkich sformułowaniach z zestawu 8, odnoszącego się do porządkowania i strukturyzowania materiału językowego. Oznacza to, że Jarek robi notatki, streszcza najważniejsze rzeczy, które przeczytał lub usłyszał w języku obcym, podkreśla, zaznacza kolorem najważniejsze informacje. Rzadziej natomiast stosuje strategie kognitywne z zestawu 5, który dotyczy ćwiczenia poprzez powtarzanie, używanie języka w celach komunikacyjnych czy w warunkach naturalnych, np. podczas czytania artykułu prasowego lub oglądania filmu w wersji oryginalnej.

Badany dość często stosuje strategie metakognitywne (średni wynik: 4,0), wśród nich zaś najczęściej te związane z planowaniem. Ze wskazań w kwestionariuszu wynika, że zazwyczaj planuje swoje uczenie i organizuje warunki do nauki, planuje czynności niezbędne do wykonania konkretnego zadania językowego, wykorzystuje każdą nadarzającą się okazję, by posługiwać się językiem. Odpowiedź „zwykle tak” pojawiła się przy wszystkich sformułowaniach zestawu 13 związanego z dokonywaniem oceny efektów uczenia się poprzez m.in. monitorowanie swoich postępów. Najrzadziej z tej grupy stosuje strategie związane z zauważaniem swoich błędów $i$ ich eliminowaniem oraz wytyczaniem sobie celów krótko- i długoterminowych.

Następne w kolejności stosowania są strategie pamięciowe (średni wynik: 3,5), z których badany dość często stosuje te związane z tworzeniem połączeń asocjacyjnych (np. „Ucząc się nowych słów, tworzę grupy wyrazowe na zasadzie podobieństw, różnic, tematów, funkcji itp.”, „Staram się łączyć nowe informacje z tym, co już wiem"). Co interesujące, uczeń stwierdza, że nie korzysta w uczeniu się ze strategii, które w kwestionariuszu zostały ujęte w zestawie 2, a obejmowały wykorzystanie obrazu i dźwięku (np. „Wykorzystuję materiały wizualne, np. obrazki, plakaty, karteczki ze słówkami itp.”, „Nowe słowa, wyrażenia kojarzę z ich brzmieniem, rytmem, intonacją itp.”, „Robię notatki za pomocą mapy myśli"). Wynika to zapewne z deficytów w obrębie funkcji analizatora wzrokowego i niskiego poziomu organizacji percepcji wzrokowej. Okazuje się jednak, że badany nie stosuje także strategii z zestawu 4 - Wykorzy- 
stanie ruchu, działania („Uczę się przez odgrywanie ról, przemieszczanie się, robienie czegoś”, „Wykorzystuję techniki mechaniczne, np. pisząc, wycinając, rysując itp."), co byłoby zgodne z jego stylem uczenia się.

Jarek w niewielkim stopniu wykształcił umiejętność stosowania strategii kompensacyjnych (średni wynik: 2,8) - dość często stosuje jedynie te związane z wykorzystywaniem wskazówek językowych, kontekstu, domyślaniem się („Wykorzystuję wskazówki językowe, np. podobieństwa z językiem ojczystym lub innym obcym”, „Domyślam się znaczenia słów z kontekstu, struktury tekstu, dzięki znajomości tematu lub ogólnej wiedzy o świecie"). Rzadziej wykorzystuje strategie ujęte w zestawie 10 - Pokonywanie ograniczeń językowych w mówieniu i pisaniu, przy czym wśród ośmiu wskaźników zawartych w tym zestawieniu znajdują się trzy, które jego zdaniem dobrze go opisują: „Szukam pomocy u innych osób”, „Wybieram temat rozmowy tak, by zasób słownictwa i struktur gramatycznych był wystarczający”, "Stosuję omówienie lub synonim”. Z pozostałych strategii nigdy lub zazwyczaj nie korzysta, np. „Wykorzystuję mimikę i gestykulację podczas rozmowy”, „Unikam pewnych tematów, wyrażeń lub zaprzestaję rozmowy, gdy pojawiają się problemy językowe”, „Dostosowuję przekaz do własnych możliwości językowych, np. upraszczam go, używam słowa podobnego do tego, które chcę wyrazić".

Badany uczeń najrzadziej korzysta ze strategii afektywnych (średni wynik: 2,6$)$. W tej grupie tylko dwa stwierdzenia zamieszczone w zestawie $14-$ Obniżanie poziomu lęku, zachęcanie się do pracy, zostały oznaczone jako „zwykle stosuję": „Staram się zrelaksować, odprężyć, słucham muzyki” oraz „Mobilizuję się do mówienia w języku obcym nawet wtedy, gdy boję się, że zrobię błąd”. Natomiast ostatni wskaźnik z tego zestawu, „Nagradzam siebie, np. jeśli powiedzie mi się na lekcji języka obcego, to sprawiam sobie jakąś przyjemność", oraz wszystkie z zestawu 15 - Świadomość własnych emocji, postaw, zostały oznaczone jako te strategie, których nie wykorzystuje nigdy: „Zwracam uwagę na własne stany emocjonalne, np. czy jestem przygnębiony, zestresowany, jeśli mi się nie powiedzie na lekcji”, „Staram się zrozumieć przyczyny takiego, a nie innego nastawienia do uczenia się języka obcego”, "Prowadzę portfolio językowe lub dziennik uczenia się albo robię notatki na temat własnej edukacji obcojęzycznej".

\section{Podsumowanie}

Jak pokazała powyższa analiza, badany uczeń nie zastanawia się nad tym, czy jego sposób uczenia się jest efektywny i czy korzysta ze wszystkich możliwości i środków, które ułatwiają uczenie się. Stosowane przez niego strategie nie są 
zgodne z preferencjami wynikającymi z indywidualnego stylu uczenia się. Zapewne wynika to też z tego, że - jak przyznał w wywiadzie - podczas całej kariery szkolnej nigdy nie był zachęcany do refleksji nad własnym sposobem uczenia się, zastanawiania się nad swoimi mocnymi stronami i ograniczeniami. Chłopiec nie wykształcił również umiejętności stosowania strategii kompensacyjnych, wykorzystuje je raczej rzadko, choć pozwalają przecież poradzić sobie w trudnej sytuacji za pomocą omówienia czy gestu. Prawie nie wykorzystuje strategii afektywnych, które pomagają regulować poziom i rodzaj własnych emocji, motywację i postawy (Komorowska, 2002: 172). Jego świadomość na temat własnego uczenia się jest niewielka. Może to jest przyczyną - obok zaburzeń o charakterze konstytucjonalnym - tego, że pracuje niewspółmiernie dużo do osiąganych efektów, a często uzyskuje wyniki poniżej swoich możliwości.

Zachęcanie do eksperymentowania w użyciu różnych technik, pobudzanie do autorefleksji nad sposobami uczenia się, nad ich skutecznością, a także nad źródłami porażek w nauce języka obcego, może być ważnym elementem wsparcia uczniów z dysleksją rozwojową. Warto, aby poznawali swój styl i swoją indywidualność, gdyż odkrywając cechy swojego umysłu, będą lepiej rozumieli swoje możliwości i ograniczenia, a przez to sprawniej się uczyli.

\section{BIBLIOGRAFIA}

Bauman, T. 2001: „Strategie jakościowe w badaniach pedagogicznych”. (w) Zasady badań pedagogicznych. Strategie ilościowe i jakościowe. (red. T. Pilch i T. Bauman). Warszawa: Wydawnictwo Akademickie „Żak”, str. 267-357.

Bogdanowicz, M. 1994. O dysleksji, czyli specyficznych trudnościach w czytaniu i pisaniu -odpowiedzi na pytania rodziców i nauczycieli. Lubin: LINEA.

Bogdanowicz, M. 2012: „Dzieci ze specyficznymi trudnościami w uczeniu się w reformującej się szkole". (w) Trudności w czytaniu i pisaniu - rozważania teoretyczne i praktyczne. (red. I. Pietras). Warszawa: Difin, str. 42-70.

Drwal, R. Ł. 1979. „Opracowanie kwestionariusza Delta do pomiaru poczucia kontroli”. Studia Psychologiczne, XVIII(1): 67-83.

DSM-IV. 2000. Diagnostic and Statistical Manual of Mental Disorders. Washington.

Dyrda, J. 2004. Style uczenia się dzieci dyslektycznych a wymagania poznawcze szkoły. Gdańsk: Wydawnictwo Uniwersytetu Gdańskiego.

ICD-10. 2002. Międzynarodowa Statystyczna Klasyfikacja Chorób i Problemów Zdrowotnych. Rewizja dziesiquta. Klasyfikacja zaburzeń psychicznych i zaburzeń zachowania w ICD-10. Opisy kliniczne i wskazówki diagnostyczne. Wyd. 2. Kraków - Warszawa. Jaworska, M. 2015. „Indywidualne style uczenia się uczniów z dysleksją a nauczanie języka obcego w szkole ogólnodostępnej”. Prace Językoznawcze, XVII(3): 55-70. Komorowska, H. 1989. „Metody ilościowe a metody jakościowe w badaniach pedagogicznych". Edukacja, 3: 14-30. 
Komorowska, H. 2002. Metodyka nauczania języków obcych. Warszawa: Fraszka Edukacyjna. Lesiak-Bielawska, E. 2007. „Styl uczenia się i jego praktyczne implikacje dla dydaktyki języków obcych". Języki Obce w Szkole, 1: 28-39.

Linksman, R. 2000. W jaki sposób szybko się uczyć. Warszawa: Świat Książki.

Nosal, C. 2000. „Różnice indywidualne w stylach uczenia się i myślenia”. Przegląd Psychologiczny, 43(4): 469-480.

Łobocki, M. 2006. Metody i techniki badań pedagogicznych. Kraków: Oficyna Wydawnicza „Impuls”.

Oxford, R. L. 1990. Language learning strategies: What every teacher should know. New York: Newbury House.

Oxford, R. L. 2002: „Language learning strategies in a nutshell: update and ESL suggestions". (w) Methodology in Language Teaching. (red. J. C. Richards i W. A. Renandya). Cambridge: Cambridge University Press, str. 124-132.

Pawlak, M. 2008: „Autonomia w nauce języka angielskiego w liceum - diagnoza, analiza, wnioski". (w) Autonomia w nauce języka obcego - co osiqgnęliśmy i dokq̨d zmierzamy. (red. M. Pawlak). Poznań - Kalisz - Konin: Wydawnictwo Uniwersytetu im. Adama Mickiewicza, str. 137-157.

Rose, C., i M. Taraszkiewicz. 2010. Atlas efektywnego uczenia (się). Warszawa: Transfer Learning Solutions.

Wilczyńska, W. 1999. Uczyć się czy być nauczanym. O autonomii w przyswajaniu języka obcego. Warszawa - Poznań: Wydawnictwo Naukowe PWN.

Wilczyńska, W. i A. Michońska-Stadnik. 2010. Metodologia badań w glottodydaktyce. Wprowadzenie. Kraków: Wydawnictwo Avalon.

Wszeborowska-Lipińska, B. 1997. „Dysleksja a zdolność i style uczenia się”. Psychologia Wychowawcza, 4: 314-330.

\section{Netografia}

Nyckowska, I. 2006. „Samoocena ucznia w uczeniu się języków obcych w klasie maturalnej". [online: http://www.ptde.org/file.php/1/Archiwum/XII/Samoocena _ucznia_w_uczeniu_si_.pdf; DW 30.08.2015]. 